\title{
A new pine pest for Diyarbakır: Observations on Buprestis (Ancylocheira) dalmatina Mannerheim, 1837 (Coleoptera: Buprestidae)
}

\author{
Halil Bolu ${ }^{1}$, Hakan Çelik ${ }^{1}$ and Hasan Maral ${ }^{2, *}$ \\ ${ }^{1)}$ Dicle University, Faculty of Agriculture, Department of Plant Protection, 21280 Diyarbakir, Turkey \\ ${ }^{2, *)}$ Karacadağ Development Agency, 21080, Diyarbakır, Turkey
}

Corresponding author: hasanmaral@ hotmail.com

\begin{abstract}
This study was conducted in 2019 on pine trees in Dicle University Campus. Bark samples were taken from the dried pine trees and brought to the laboratory. Samples were cultured in plastic containers in $26 \pm 1^{\circ} \mathrm{C}, 65 \pm 5 \%$ humidity and climatic chambers set to 16: 8 period. As a result of this study, Buprestis (Ancylocheira) dalmatina Mannerheim, 1837 species belonging to Buprestidae family of Coleoptera was determined. This is the first record for pine trees in Diyarbakir. In addition, this species is the first record for the insect fauna of Diyarbakır. This harmful species, which is one of the rare insect species in the world, is thought to have entered the province of Diyarbakır, possibly through production materials brought to the region without supervision.
\end{abstract}

Keywords: Pine, Buprestis (Ancylocheira) dalmatina, Diyarbakır, new record, internal quarantine.

\section{Introduction}

Insects (Hexapoda) are the group of animals with the largest number of species with more than one million species described in the world (Price 1997). Consistent estimates reveal that $50-90 \%$ of existing insect species on Earth are still undiscovered. However, it reveals that identified insects contain more than half of all known organism species. Insects make up the most diverse form of animal life in terrestrial ecosystems. Many species are harmless and essential components of the natural ecosystem. Since they are cold-blooded, the rates of key physiological processes in their life cycle are determined by environmental conditions, especially temperature and humidity. In general, they have short generation periods, high fertility rates and high mobility. (Moore and Allard 2008).

Although Anatolia is not a continent, it contains all the features of a continent in terms of an ecosystem and habitat features, and it looks like a small continent in terms of biodiversity. Each of the seven geographical regions of Turkey has a distinctive climate, flora, and fauna.

Species belonging to the Buprestidae family are generally common in tropical and subtropical regions. Their length varies between 3-80 mm. Many of them are metallic, green, black, and in different colors. The last part of their body is tapered. The head is recessed, and embedded. Antennas are sawed. Most adults feed on flowers and leaves. The larvae cause main damage by opening galleries in the roots, stems, branches, and shoots of the trees. 
The pine tree species of the Pinaceae family belonging to the genus Pinus are among the most common trees in Turkey. Pine trees are mostly coniferous, and evergreen trees. However, there are also shrub forms. Pine trees grow in climatic regions, which vary by species. Pine trees grow well in sunny areas. Most species need very little water once they bloom. They develop relatively well on permeable soils.

In Turkey, pest control is carried out against about 50 harmful insects, plants, fungi, mites, bacteria, and virus species in an area of 500 thousand hectares of forest. Around 8-10 million TL is spent annually for these efforts. It is known that the damage of insects in the forests is much more than the bushfires damage (Eroğlu 2017). The most important of the insects that damage the trees are the species that live in cambium and tissues close to cambium. Although these insects are called "cambium insects", their main and larvae pathways (eggs and larvae cavities) are in the phloem. These are also called "phloem beetles". The large group of these insects is members of the Curculionidae, Scolytinae (Curculionidae), Cerambycidae and Buprestidae families of the Coleoptera order (Eroğlu 2017).

This study aims to determine the Buprestis (Ancylocheira) dalmatina species belonging to the Buprestidae family, which are harmful in pine trees and to investigate its some morphological features.

\section{Material and Methods}

This study was carried out on pine trees (Pinus parviflora) in Dicle University Campus, Faculty of Agriculture, in 2019. The study area $\left(37^{\circ} 53^{\prime} 31.8^{\prime \prime} \mathrm{N} 40^{\circ} 16^{\prime} 22.2^{\prime \prime} \mathrm{E}\right)$ is consisting of 895 pine trees, 82 of them are blue cypress (Cupressus arizonica) and 813 of them are Persian pine (Pinus parviflora). Samples of dried out pine trees were taken and brought to the laboratory (Figure 1).

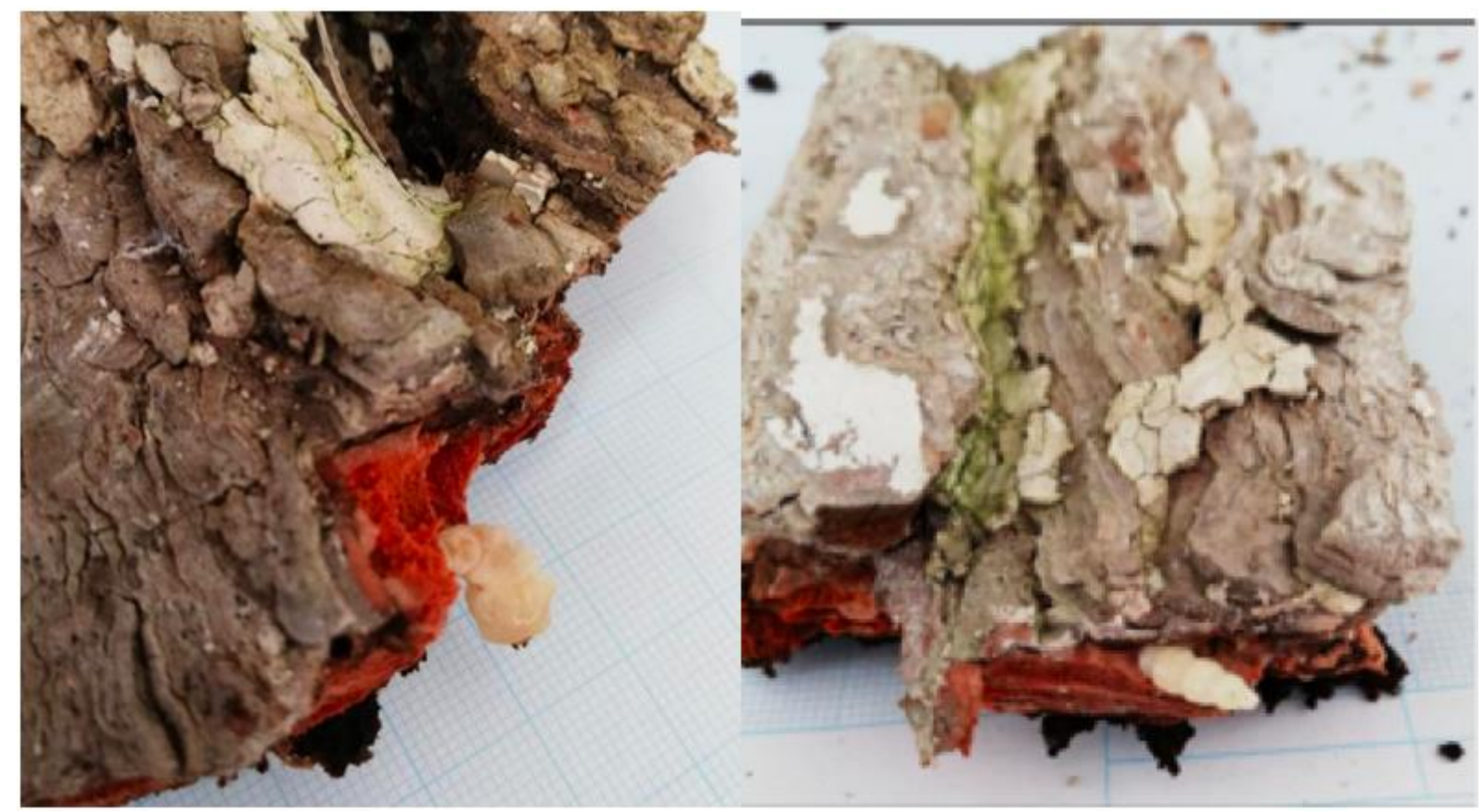

Figure 1. Pine tree shells, infected with the larvae of the pest.

The samples brought to the laboratory were divided into small pieces and placed in $20 \times 20 \times 30 \mathrm{~cm}$ plastic containers covered with thin cheesecloth. They were then cultured in climatic chambers set at $26 \pm 1{ }^{\circ} \mathrm{C}, 65 \pm 5 \%$ humidity, and 16: 8 light / dark period. The identification of the sample obtained as a result of the study was made by Prof. Dr. Göksel Tozlu (Atatürk University, Faculty of Agriculture, Department of Plant Protection, Erzurum). Measurement (by digital caliper) and weighing's (by digital precision scales) were made on the adults. 


\section{Results and Discussion}

As a result of the study, Buprestis (Ancylocheira) dalmatina Mannerheim, 1837 species belonging to Buprestidae family was determined.

\section{Synonyms}

=Buprestis (Buprestis) dalmatina Mannerheim, 1837

=Buprestis (Buprestis) flavostrigata Frivaldszki, 1845

=Buprestis (Buprestis) ledereri Marseul, 1865

=Buprestis (Buprestis) semiviridescens Pic, 1918

Distribution in the World: Italy (Lorubio et al. 2018); Albania, Bosnia and Herzegovina, Bulgaria, Croatia, Cyprus, East Palaearctic, European Turkey, Greek mainland, Kriti (Crete), Macedonia, the former Republic of Yugoslavia, Near East, Slovenia, Ukraine, Vóreion Aiyáion (North Aegean Is.), Cyprus, Syria, Egypt (Obenberger 1941, Niehuis 1990, Kubáň 2016, Alonso-Zarazaga 2019a).

Distribution in Turkey: East Black Sea Region (Yüksel 1998); Sakarya (Sakalian 2003); Karabük, Kastamonu, Sinop (Yalçın et al. 2019); Antalya (Slutsky 2019b).

Recorded Host Plants in the World: Pinus halepensis Mill. (Lorubio et al. 2018).

Recorded Host Plants in Turkey: Eastern spruce [Picea orientalis (L.)] (Yüksel 1998); Pinus sp. (Sakalian 2003); yellow pine (Pinus sylvestris) (Yalçın et al. 2019).

\section{Adult period}

In the study, 147 Buprestis (Ancylocheira) dalmatina adults were obtained from larvae cultured in the laboratory (Figure 2).

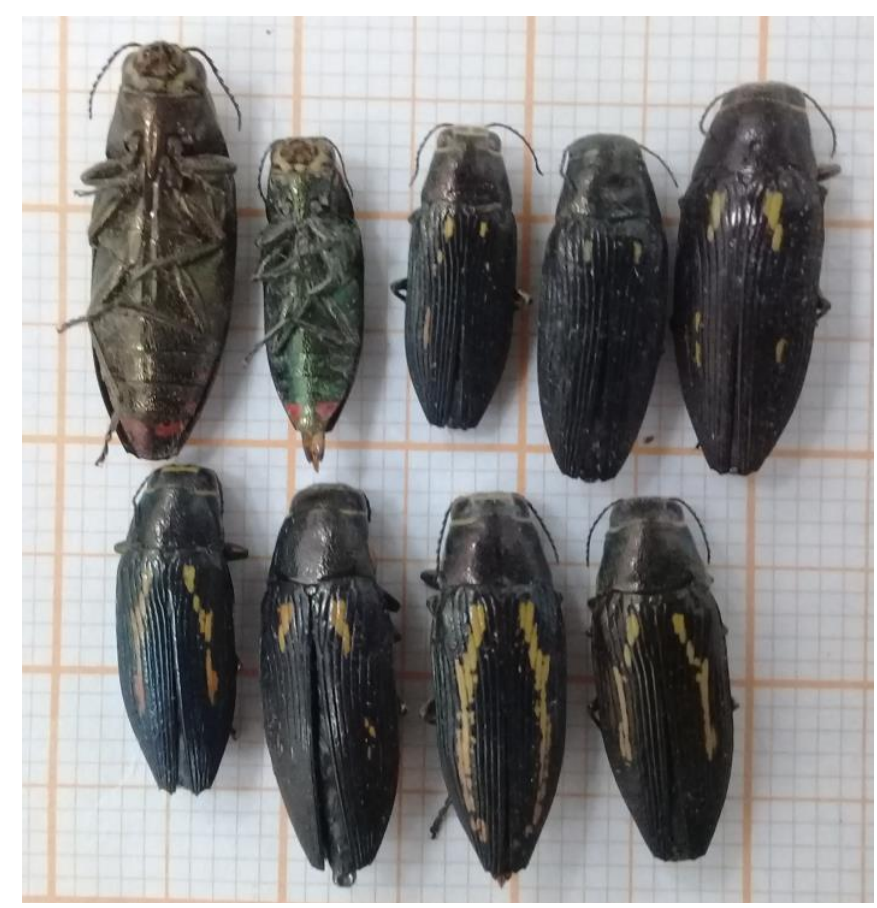

Figure 2. Adult period of Buprestis (Ancylocheira) dalmatina.

Among the 147 individuals obtained as a result of the study, measurements were made on 22 individuals randomly selected (Table 1). 
Table 1. Height and weight values of Buprestis (Ancylocheira) dalmatina

\begin{tabular}{llll}
\hline & Minimum & Maximum & Average \\
\hline Height $(\mathrm{mm})$ & 12,27 & 17,31 & $14,3536 \pm 1,39190$ \\
Weight $(\mathrm{gr})$ & 0,016 & 0,032 & $0,2218 \pm 0,005612$ \\
\hline
\end{tabular}

Adult period is easily recognized by the golden yellow bands on the metallic black elytron (Figure 3).

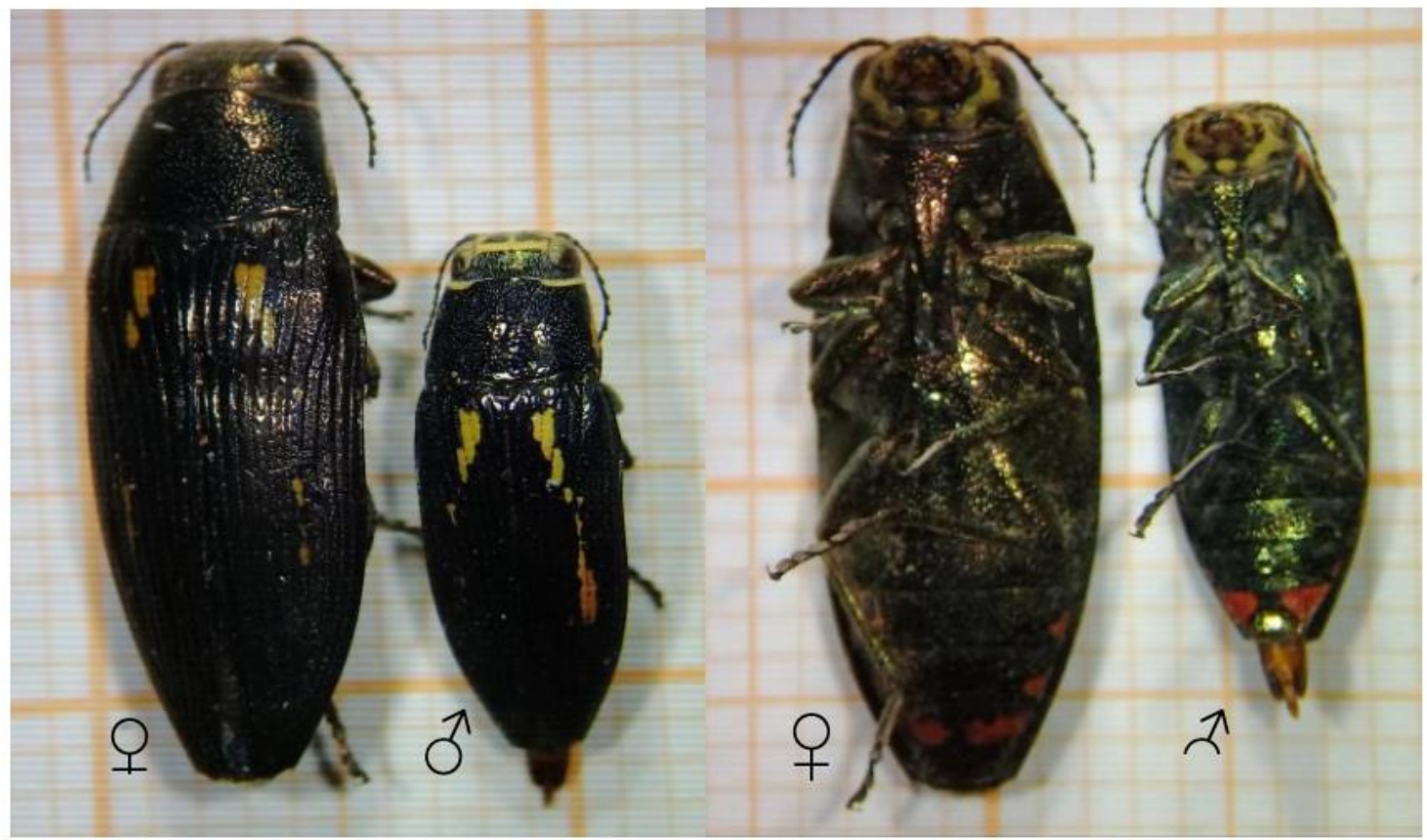

Figure 3. Dorsal and ventral view of the female (ㅇ) and male ( $\overbrace{}^{\Uparrow})$ of Buprestis (Ancylocheira) dalmatina.

\section{Larval stage}

The length of the last stage larvae of the pest reaches approximately $3 \mathrm{~cm}$. The head width of the larva is around $7 \mathrm{~mm}$ (Figure 4).

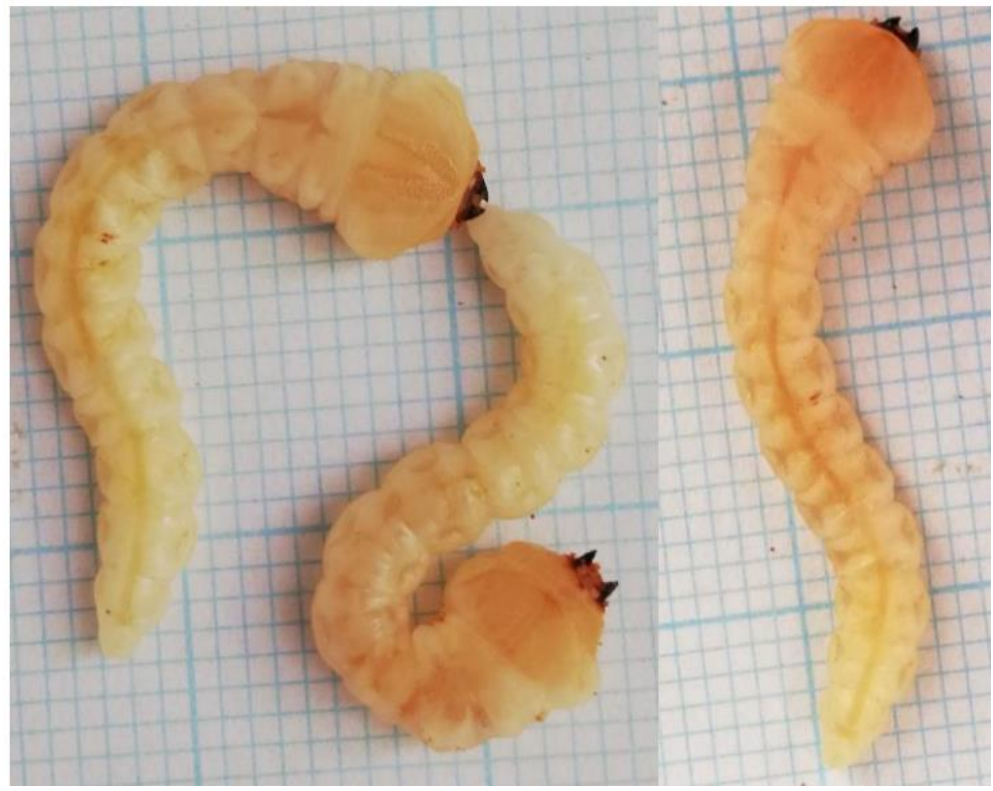

Figure 4. The last larval stage of Buprestis (Ancylocheira) dalmatina. 


\section{Pupae stage}

In the observations, The larvae of Buprestis (Ancylocheira) dalmatina prefer the bark of pine trees to turn into pupae (Figure 5).

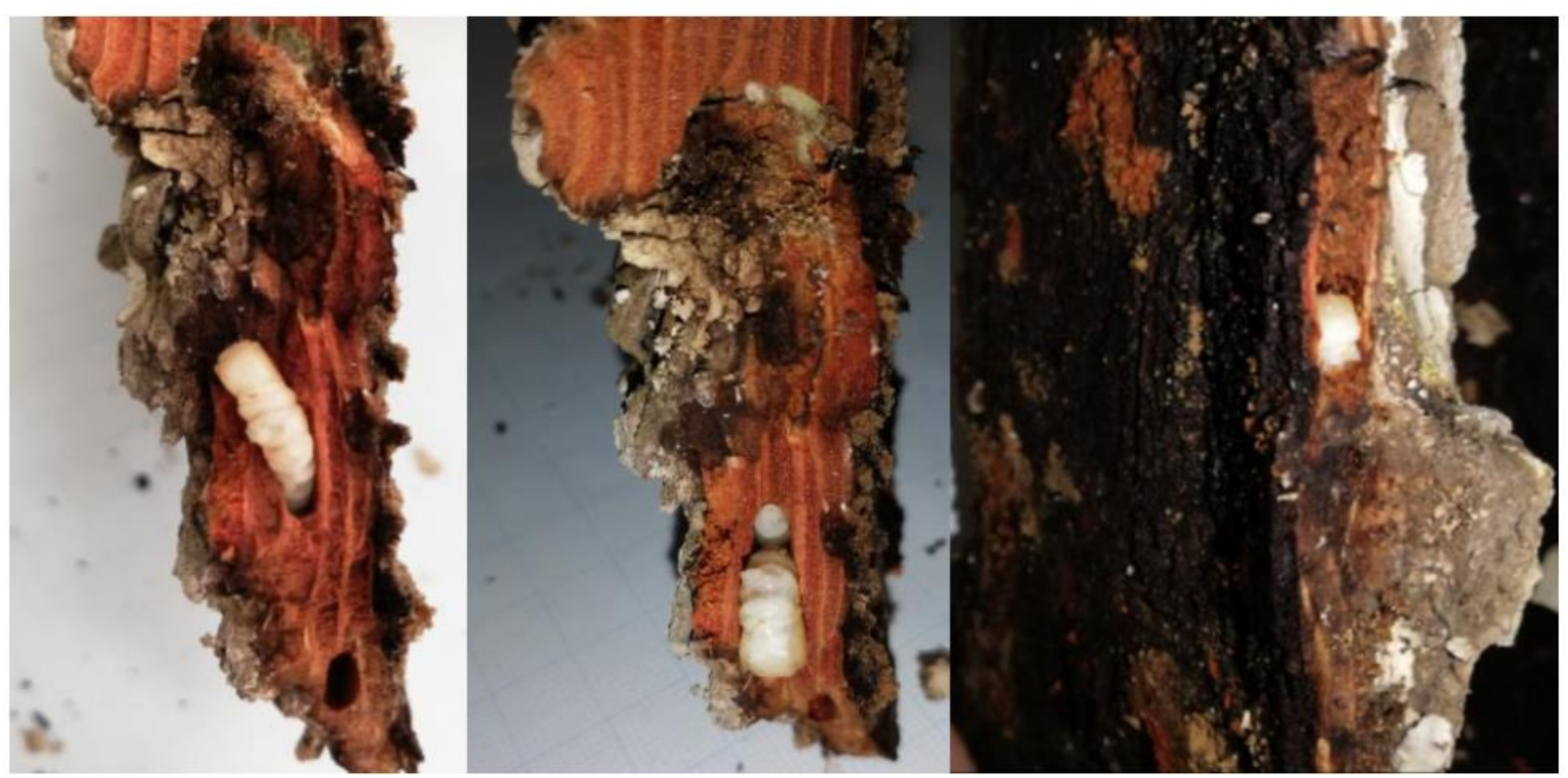

Figure 5. Buprestis (Ancylocheira) dalmatina's prepupa stage in the Pine tree shells.

The average length of the pupae of Buprestis (Ancylocheira) dalmatina was measured as $17 \mathrm{~mm}$ and the width as $7 \mathrm{~mm}$ (Figure 6).

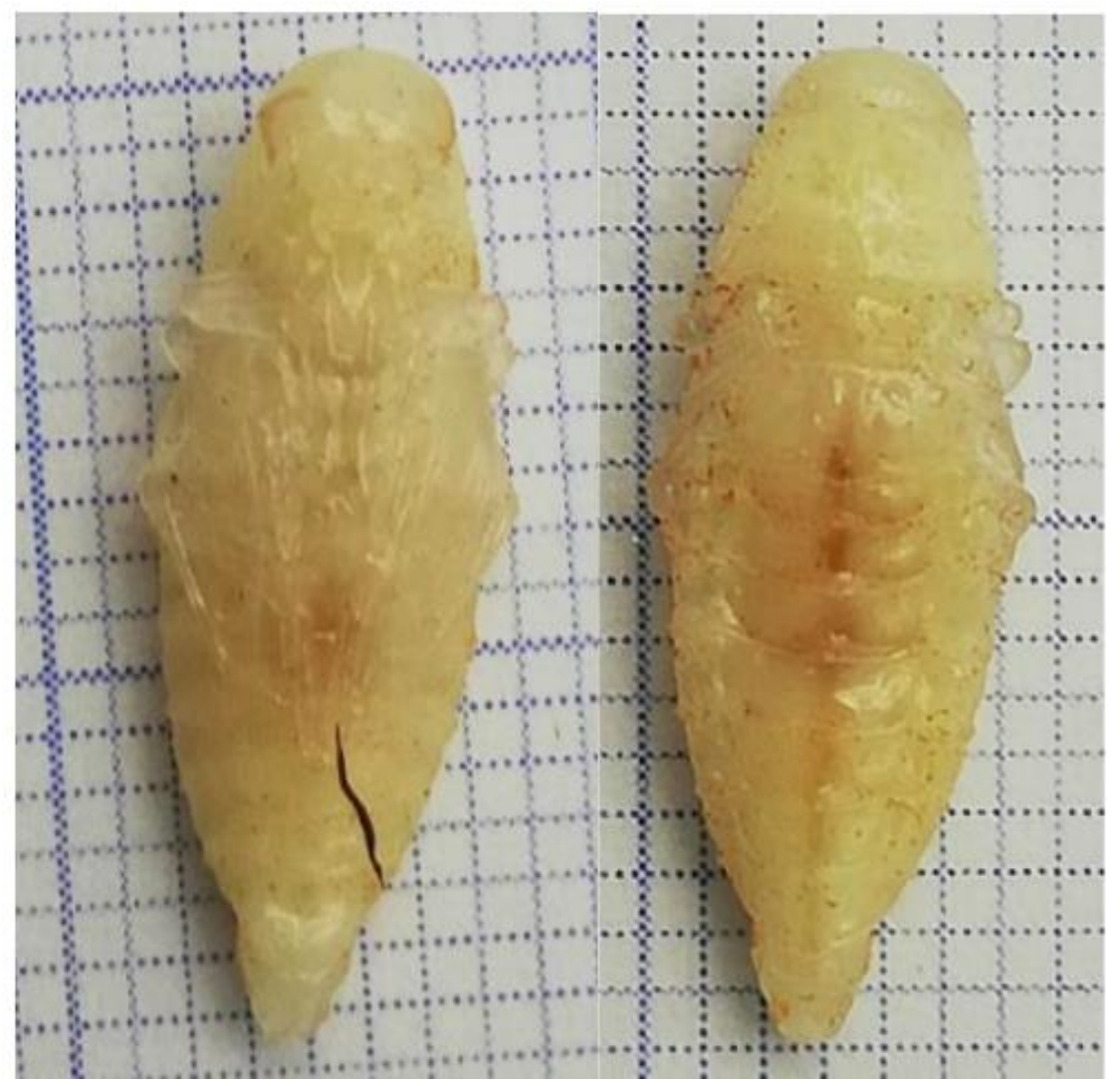

Figure 6. Dorsal (left) and ventral (right) view of the pupae of Buprestis (Ancylocheira) dalmatina. 


\section{Damage}

The harm of the adult of Buprestis (Ancylocheira) dalmatina does not matter. The main damage is made by larvae. The larvae of the pest feed on the wood tissues of pine trees. The trunks of pine trees suffer great damage as a result of feeding the larvae (Figure 7-8).

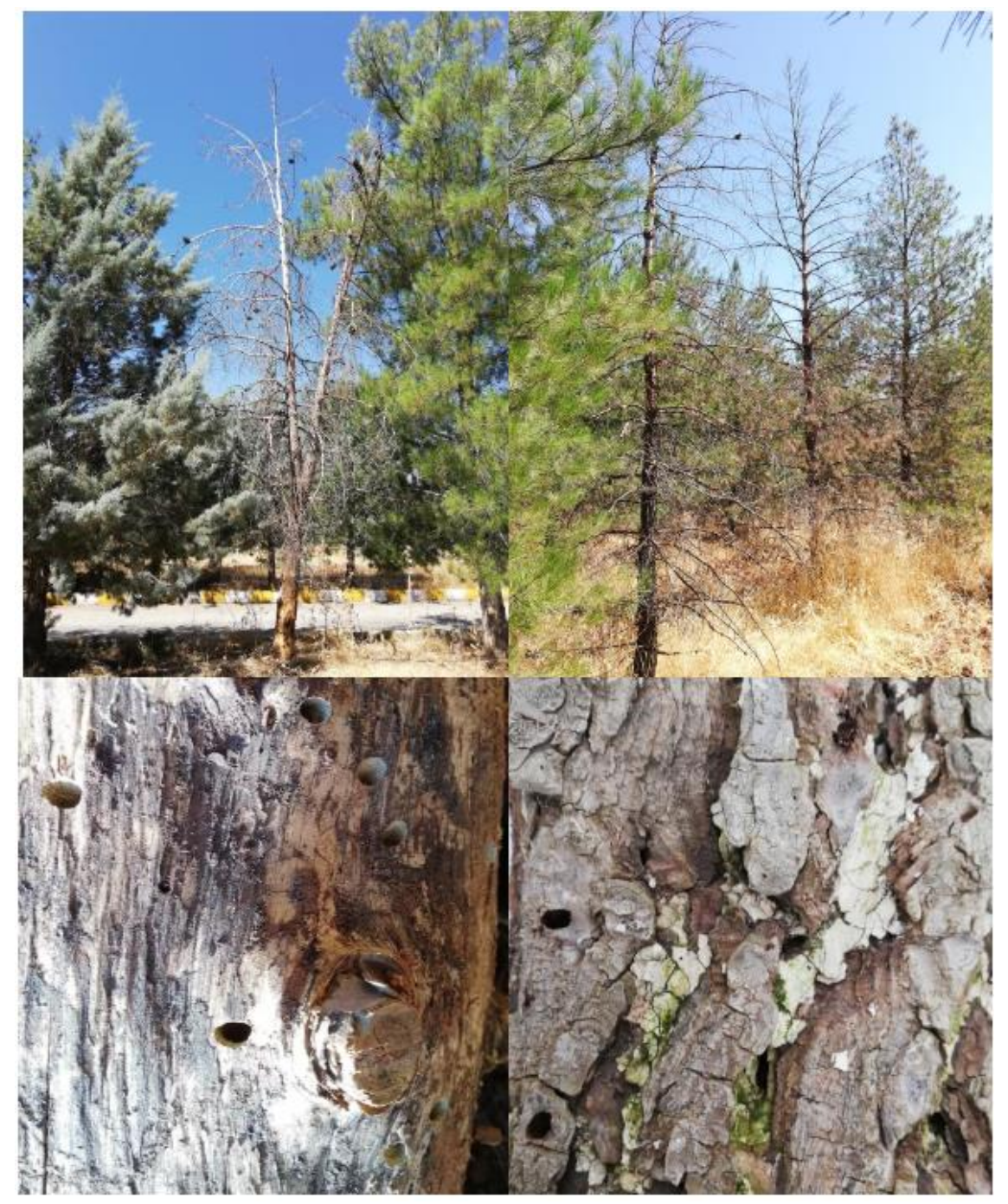

Figure 7. Pine trees attacked by larval periods of Buprestis (Ancylocheira) dalmatina.

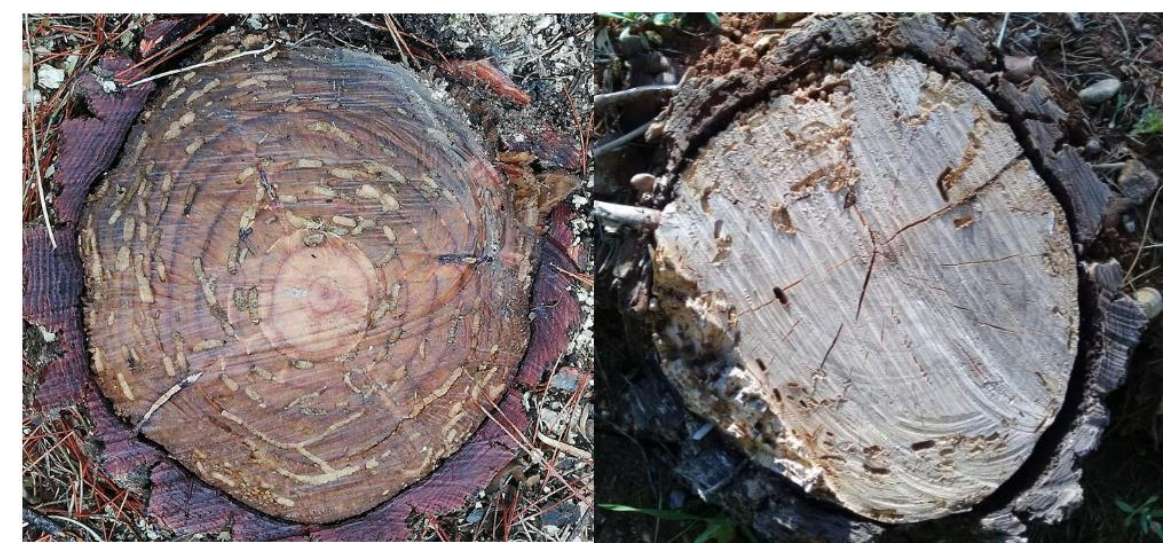

Figure 8. Horizontal section of pine trees attacked by larvae stages of Buprestis (Ancylocheira) dalmatina. 
Buprestid species mainly cause significant damage by feeding on plants' woody stem tissues. As a result of their feeding, they can dry the host plants completely or partially in a short time. For this reason, the damages caused by the feeding holes of larvae are very important. The species belonging to the Buprestidae family, which is the primary pest, causes the secondary harmful insect species to settle on the plants as well as their direct harm.

Buprestis (Ancylocheira) dalmatina is not a common species in Turkey. In previous studies, low numbers of Buprestis (Ancylocheira) dalmatina adults were obtained on Pinus species (Sakalian 2003, Yalçin et al. 2019).

In conclusion, how this species, which is rarely found in pine trees in different regions in Turkey, is transmitted to a local area in Diyarbakır is thought-provoking in terms of internal quarantine. There is very little information about the biology, ecology and natural enemies of this species in Turkey and in the world. This harmful species, which is one of the rare insect species in the world, is thought to have entered the province of Diyarbakır, possibly through pine saplings brought to the region without supervision. Similar to this finding in our study, Lorubio et al. (2018) stated that B. dalmatina, which was first found on $P$. halepensis in Italy, may have been infected by pine saplings brought from the Balkans.

In our study area, established in 2003 within the campus of the Faculty of Agriculture of Dicle University, there are 895 pine trees, 82 of them are blue cypress and 813 of them are Persian pine. The picture of dried pine trees taken in 2019 (Figure 9a), and the picture of gaps formed as a result of cutting the dried trees taken in 2020 (Figure 9b), are clearly visible. In the observations made in the study area, because of the damage of Buprestis (Ancylocheira) dalmatina, 90 Persian pine trees corresponding to approximately $10 \%$ of the area were completely dry and 58 of them were cut. It was seen that there were some dry trees in other pine area close to the study area.

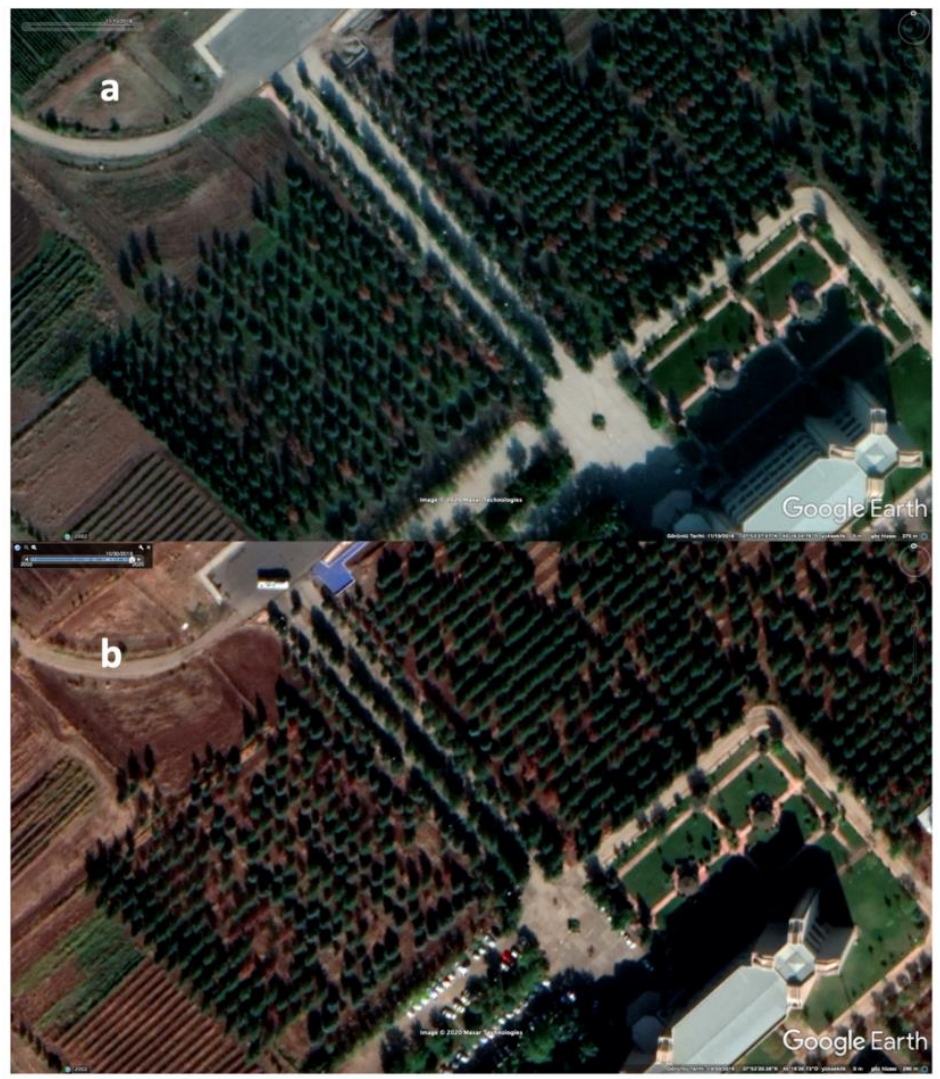

Figure 9. The picture of dried pine trees taken in 2019 (a), and the picture of gaps formed as a result of cutting the dried trees taken in 2020 (b). 
Buprestis (Ancylocheira) dalmatina, which is quite destructive, needs to be watched carefully. It is important to focus on the recognition, biology, natural enemies and control methods of this species. In this study, it was observed that this species fed with Persian pine (Pinus parviflora) did not prefer the blue cypress (Cupressus arizonica) species in the same area. In addition, it is necessary to carefully monitor whether this harmful species also exhibits a specialization in terms of nutrition preference. We believe that this study will form the basis for further research planned to be conducted on Buprestis (Ancylocheira) dalmatina in the future.

\section{Acknowledgements}

We are thankful to Mr. Prof. Dr. Göksel Tozlu (Atatürk University, Faculty of Agriculture, Department of Plant Protection, Erzurum), who made the identification of Buprestis (Ancylocheira) dalmatina.

\section{References}

Alonso-Zarazaga, M.A. (group coordinatır) (2019a). Fauna Europaea. https://faunaeu.org/cdm_dataportal/taxon/4052a91e-0b31-4fdb-a829-c48938319f11 (Visited on date: 12/07/2019).

Eroğlu, M. (2017). Orman Zararlılarının Yönetimi. Karadeniz Teknik Üniversitesi, Orman Fakültesi, Orman Mühendisliği Bölümü, Trabzon, 204 pp.

Kubáň, V. 2016. Buprestinae. In Löbl I. \& D. Löbl (eds.). Catalogue of Paleartic Coleoptera. Volume 3, Scarabaeoidea, Scirtoidea, Dascilloidea, Buprestoidea and Byrrhoidea. Revised and updated edition. Leiden, Boston. Brill.

Lorubio, D., Cancelliere, G., Izzillo, F. (2018). First records of acclimatized populations of Buprestis dalmatina in Italy (Coleoptera: Buprestidae). Fragmenta entomologica, 50(1), 53-56.

Moore, B., Allard, G. (2008). Climate change impacts on forest health. Forest Health and Biosecurity Working Paper FBS/34E, Rome, FAO.

Niehuis, M. 1990. Beitrag zur Kenntnis Buprestis Arten des Nahen Ostens (Coleoptera: Buprestidae). Zoology in the Middle East, 4: 39-60.

Obenberger, J. 1941. Revision der palaearktischen Buprestis Arten (Coleoptera, Buprestidae). Mitteilungen der Münchner Entomologischen Gesellschaft, 31 (2): 460-554.

Price, P.W. (1997). Insect Ecology. John Wiley \& Sons Inc., New York, 874 pp.

Sakalian, V. (2003). New Data for the distribution of Jewel Beetles (Coleoptera: Buprestidae) in Turkey. Acta Zoologica Bulgarica, 55(1), 5-10.

Slutsky, A. (editör) (2019b). Alsphotopage. http://www.alsphotopage.com/gallery/index/id/930 (Visited on date: 13/07/2019).

Yalçın, M., Akçay, Ç., Taşçıŏlu, C., Yüksel, B. (2019). Insect species damaging industrial wood in Western Black Sea Region of Turkey. Scientific journal of wood technology, 70(2), 183-191.

Yüksel, B. (1998). Doğu Ladini (Picea orientalis (L.)) Ormanlarında Zarar Yapan Böcek Türleri ile Bunların Yırtıcı ve Parazitleri-II (Yırtıcı ve Parazitler). T.C. Orman Bakanlığı Doğu Karadeniz Ormancılık Araştırma Enstitüsü, Teknik Bülten, No: 6, 90 pp.

Submitted: 03.07.2020 Accepted: 27.08.2020 